\title{
Against the Elements: Sir Humphry Davy
}

His name isn't a household word, but the accomplishments of British chemist Sir Humphry Davy have had ramifications for most of the physical sciences.

Not only did he work on theories of light and heat, he also isolated 10 new elements. He investigated the anesthetic and medical properties of various gaseous mixtures...he developed the foundations of electrochemistry...and he even invented a safety lamp for coal miners that would not explode in the high concentrations of methane found in some mines.

Davy was born December 17, 1778 at Penzance, Cornwall England. His parents were well-to-do, his father a wood-carver. He wasn't an avid student but studied classics and had a fondness for poetry and fishing, interests that lasted all his life.

Unfortunately, Davy's father died in the middle of the young man's schooling, leaving a $£ 1,300$ debt. In 1794 Humphry Davy had to return to Penzance to help support his family, which now consisted of his mother and four younger brothers. Davy was apprenticed to a surgeon-apothecary, J. Bingham Borlase.

Davy continued to read and study on his own, though. In 1797 he read Antoine Lavoisier's Elcmentary Treatise on Chemistry, and his dreams of becoming a poet "fled before the voice of truth." His first extended scientific attempt was to disprove Lavoisier's theory of light and heat.

Within a couple of years working at the surgeon-apothecary's, Davy was investigating the various therapeutic properties of gases. He had the unfortunate habit of breathing new gaseous mixtures to test their effects on himself, nearly suffocating several times after breathing pure carbon dioxide or hydrogen. He did discover the intoxicating effects of nitrous oxide and suggested that it might be used as a medical anesthetic. |Actually, it became more popular among the upper classes for use as a recreational drug.]

Davy's greatest contribution, though, lies in electrochemistry. After reading about Allesandro Volta's voltaic cell in 1800, and of the work of William Nicholson and Anthony Carlisle who found that passing an electric current through water could break it down into hydrogen and oxygen, Davy decided to investigate the electrolysis of aqueous solutions. He theorized that electrolysis itself could be explained by oppositely charged chemical species, which could be arranged on a scale of relative affinities. He also suggested that electrolysis could be put to large-scale use in the alkali industry.

In 1801 he moved to the Royal Institution of London, where he worked with Count Rumford and Henry Cavendish. He improved the batteries commonly used in experiments and in 1805 created the first electric arc. One of his batteries contained over 250 metal plates, the strongest ever built at that time.

Many substances were suspected of containing metallic elements that had been so tightly bonded to oxygen that they could not be separated by strong heating processes. In 1806 Davy suggested that using electric currents to investigate solutions of these materials would lead to a more detailed knowledge of the "true elements of bodies."

On October 6, 1807 Davy passed a current through molten potash, which liberated elemental potassium. He saw little balls of shining metal hissing and sputtering under a lavender flame as the potassium recombined with oxygen. Davy danced about the room in delight and likened his new element to something the old alchemists might have imagined. A week afterward he similarly isolated sodium from soda.

In 1808 Davy isolated calcium from lime, and magnesium from magnesia. He also found strontium, barium, and silicon. That year he also isolated boron by heating borax with potassium, but another researcher, Gay-Lussac, had done the same thing a mere nine days before.

In 1809 Davy melted alumina with iron and named the resulting metal alumium, then changed it to aluminum, and later to aluminium (a name still in use today in Britain). In his investigations he was confused by ammonium amalgam, a pasty material resulting from ammonium salts electrolyzed by a mercury cathode. Davy and his contemporaries erroneously believed this proved the elemental nature of "ammonium."

Two years later Davy engaged in a quantitative study of muriatic acid (hydrochloric acid). He found that electricity did not affect the green gas resulting from its decom- position, and decided that this gas was also an element, which he named chlorine from a Greek word for "green."

Remember, all this was from a man who had no formal training in chemistry, only what he read and reasoned for himself. He did not take much stock in any theoretical system, claiming that the only value of hypotheses was that they led to new experiments.

Davy's health began to suffer-not surprising, considering his habit of sniffing and inhaling any sort of chemical gas he created. He damaged his eyes in 1812 in a nitrogen trichloride explosion.

In 1813 Davy took on a new laboratory assistant, Michael Faraday, who would later surpass even his mentor's prodigious scientific accomplishments. Faraday accompanied Davy on a tour of Europe.

During the tour, Davy went to Genoa to study the electric torpedo-fish, then went to Florence where he used the great burning glass of the Accademia del Cimento to burn the Duke of Tuscany's diamond in oxygen. The results of this experiment led him to conclude that diamond is composed essentially of pure carbon. In France, Davy saw the similarities between chlorine and a substance that formed purple fumes, and announced another new element, iodine.

Davy won many awards and honors for his scientific work, including several French medals (even though England and France were at war at the time). He was knighted by the Prince Regent in 1812, and married a wealthy widow three days later.

In 1818 Davy tried to unravel papyruses found at Herculaneum by using chlorine to break down the gummy matter holding them together. Also that year he became a baronet, and two years later he was named the president of the Royal Society.

Later, Davy returned to his earlier fascination with geology, and proposed a theory to explain volcanic eruptions-that volcanoes had a core of alkali metal, which was acted on by water; the resulting explosion hurled lava to the surface.

Throughout his life, Davy continued to pursue his boyhood interests of fishing, sketching, and poetry. Indeed, when he became a well-known scientist, he began to move in social circles that brought him in contact with great poets such as Wordsworth and Coleridge. He became friends with Coleridge and shared some of his verses, which Coleridge greatly admired. Complimenting his poetry, Coleridge wrote of Davy, "If he had not been the first chemist he would have been the first poet of his age."

KEVIN J. ANDERSON 